\title{
Survival of pathogens on soybean debris under no-tillage and conventional tillage systems ${ }^{(1)}$
}

\author{
Álvaro Manuel Rodrigues Almeida ${ }^{(2)}$, Odilon Ferreira Saraiva ${ }^{(2)}$, José Renato Bouças Farias(2), \\ Celso Almeida Gaudêncio(2) and Eleno Torres ${ }^{(2)}$
}

\begin{abstract}
A study was conducted in the subtropical area of Southern Brazil to determine the survival of pathogens in soybean residues under conventional and no-tillage cultivation systems from March to September of 1998 and 1999. The pathogens most frequently isolated were Colletotrichum truncatum, Phomopsis spp., Cercospora kikuchii, Fusarium spp., Macrophomina phaseolina, and Rhizoctonia solani. Other fungi isolated were Myrothecium roridum, Penicillium sp., Chaetomium sp., Epicoccum sp., Corynespora cassiicola and Trichoderma sp. The percent of survival of each pathogen varied according to the month and the year. Survival of C. truncatum, Phomopsis spp. and C. kikuchii were significantly reduced $(p<0.05)$ from the first to the last evaluation either on buried debris or maintained on the soil surface. On the other hand, M. phaseolina and Fusarium spp. were either not affected or favored by burying the debris. The frequency of recovery of Fusarium spp. increased specially in debris kept under the soil. The loss of biomass, measured by debris weight along the period of this study, showed a reduction of $44.4 \%$ in the conventional system and $34.9 \%$ in the no-tillage system in 1998 , when rain was better distributed. In 1999 , the reduction was $48.2 \%$ and $39.0 \%$ for the conventional and no-tillage system, respectively.
\end{abstract}

Index terms: cultivation, crop residues, degradation, biomass, plant diseases.

\section{Sobrevivência de patógenos em restos de cultura de soja mantidos em sistema de semeadura direta e convencional}

Resumo - Avaliou-se a sobrevivência de patógenos em restos de soja, em sistema de semeadura direta e convencional, entre março e setembro de 1998 e 1999, em Londrina, PR. Os patógenos mais freqüentemente isolados foram Colletotrichum truncatum, Phomopsis spp., Cercospora kikuchii, Fusarium spp., Macrophomina phaseolina e Rhizoctonia solani. Outros fungos isolados foram Myrothecium roridum, Penicillium sp., Chaetomium sp., Epicoccum sp., Corynespora cassiicola e Trichoderma sp. A porcentagem de sobrevivência variou com o mês e o ano. A sobrevivência de C. truncatum, Phomopsis spp. e C. kikuchii foi significativamente reduzida $(\mathrm{P}<0,05)$ entre a primeira e última avaliação nos resíduos mantidos sobre ou sob o solo. M. phaseolina e Fusarium spp. não foram afetados, ou foram favorecidos pelo enterro dos resíduos. A freqüência de isolamento de Fusarium spp. aumentou em resíduos enterrados no solo. A perda de biomassa mostrou redução de $44,4 \%$ no sistema convencional e $34,9 \%$ no sistema de semeadura direta, em 1998, quando a distribuição de chuvas foi mais regular. Em 1999, a redução foi de 48,2\% e 39,0\% para os sistemas convencional e de semeadura direta, respectivamente.

Termos para indexação: cultivo, resíduos de colheita, degradação, biomassa, doenças das plantas.

(1) Accepted for publication on November 11, 2000

(2) Embrapa-Centro Nacional de Pesquisa de Soja, Caixa Postal 231, CEP 86001-970 Londrina, PR. E-mail: almeida@cnpso.embrapa.br,odilon@enpso.embrapa.br, jrenato@cnpso.embrapa.br, celso@cnpso.embrapa.br eleno@cnpso.embrapa.br

\section{Introduction}

Brazilian soils are generally very sensitive to erosion both by rain or wind. Therefore, soil management for conservation has been achieved through the use of crop rotation and no-tillage. In the last ten 
years, there was an increase in no-tillage system in the country reaching a total of 9 million ha in 1998 (Saturnino, 1998). Unfortunately soybean residue left on the soil surface decays slower than buried debris increasing the survival of necrotrophic pathogens (Roncadori et al., 1975; Cook et al., 1978; Rothrock et al., 1985). Pathogens that remain alive in soybean debris constitute the source of primary inoculum in the field (Kmetz et al., 1979). According to Baird et al. (1997), soybean debris from a no-till area harbors numerous pathogenic fungi that could increase soybean diseases at the following season, thus reducing yields.

Under Brazilian conditions, a previous study (Almeida, 1980) reported that burying residues reduced survival of fungi such as Cercospora kikuchii, Colletotrichum truncatum and Phomopsis sojae while the soilborne pathogens Rhizoctonia solani, Macrophomina phaseolina and Fusarium spp. increased.

Results from Adee et al. (1997) showed that brown stem rot was more severe in soybean plants under no-tillage system. However, they also observed that total inoculum during the fallow period decreased due to the loss of biomass. Costamilan et al. (1999) observed that it took 27 months to completely degrade the soybean residues in Southern Brazil. In a different study, Saraiva \& Torres (2000) compared the effect of tillage and no-tillage systems on soybean degradation and reported that mineralization was faster under tillage with a reduction in biomass of $65.8 \%$ and $60.9 \%$ for 1998 and 1999 , respectively.

The effect of crop rotation on soil population of Fusarium solani was evaluated by Rupe et al. (1997). They concluded that averaged over all years, population of $F$. solani was significantly lower when sorghum or wheat were grown than with soybean or fescue.

The effects of conservation tillage on soybean diseases are not fully understood. In Brazil very few studies have been conducted to determine the benefits or problems associated with crop residues remaining on the soil surface particularly in regard to disease outbreaks. It is generally believed that no-tillage will increase the potential for diseases by allowing the residues to remain on the soil surface allowing greater pathogen survival from one cropping season to the next.

The objective of this study was to evaluate the survival of pathogens on soybean debris kept on and in the soil, from harvesting till the next sowing time.

\section{Material and Methods}

The study was conducted in plots in Londrina, PR, Brazil, that had been under either continuous tillage or no-tillage for 16 years. The climate in this region is defined as Cfa according to Köppen (1918), cited by Strahler (1975). The soil type was an Oxisol (Latossolo Roxo distrófico), Haplorthox (American Soil Taxonomy), with $67 \%$ clay, $17 \%$ silt, and $16 \%$ sand in the Ap horizon.

Immediately after harvesting, soybean cv. EMBRAPA 37 residues were separated in pods, petioles, stems and roots. One hundred grams of each part were placed inside polypropylene mesh bags (mesh size $4 \mathrm{~mm}^{2}$ ). Petioles and stems were placed in the same bag. Bags of each tissue type were either buried at $10 \mathrm{~cm}$ depth or kept on the soil. At harvest and then at one month intervals, $5 \mathrm{~g}$ of each bag was collected and washed under running water. Fragments around $0.5 \mathrm{~cm}$ long were cut, disinfested in $95 \%$ ethanol for $30 \mathrm{sec}$, transferred to $0.6 \%$ sodium hypochloride solution for $1 \mathrm{~min}$, washed in sterile water and then transferred to plates containing PDA and streptomycin sulphate $(10 \mathrm{mg} / \mathrm{L})$ to avoid bacterial contamination. For each sample, seven plates with three fragments each were used. Plates were incubated at $26^{\circ} \mathrm{C}$ for eight days and the number and type of each fungus was recorded. Results were recorded on a percentage basis for each fungus species based on the total number of isolates in all seven plates as $100 \%$. Unidentified fungi were considered in the total number of isolates. Fusarium isolates were subcultured on PDA for later identification.

This study was conducted during the fallow seasons of 1998 and 1999. A completely randomized design was used, considering two evaluation times (March and September), two tillage systems (conventional and no-tillage), and three types of debris (pods, stem and roots) with a total of 12 treatments. Each treatment was replicated seven times and each plate with three fragments was considered one replication. Duncan's multiple range test was used to compare percentage of fungi survival of the first and last evaluation.

In another experiment the rate of soybean residue mass loss under conventional and no-tillage systems was evaluated. Immediately after harvesting, soybean debris, mostly stems and pods were collected, cut into $5 \mathrm{~cm}$ pieces, dried at $70^{\circ} \mathrm{C}$ until constant weight and placed in polypropylene 
mesh bags (mesh $1 \mathrm{~mm}^{2}$ ). Bags containing $12 \mathrm{~g}$ of soybean debris were either buried at $15-20 \mathrm{~cm}$ or kept on the soil surface after the establishment of the winter crop (wheat). Bags were collected after $0,1,2,4,8$ and 16 weeks. Debris were washed, dried and weighted. The experimental design was a randomized complete block with two treatments (conventional and no-tillage) with four replications per treatment. Meteorological data were provided by an automatic weather station (Campbell Sci., Inc., Logan, UT, USA).

\section{Results and Discussion}

Pathogens most frequently isolated from soybean debris were Colletotrichum truncatum, Phomopsis sojae, Cercospora kikuchii, Fusarium spp., Macrophomina phaseolina, and Rhizoctonia solani. They accounted for $70 \%$ of the total isolates obtained
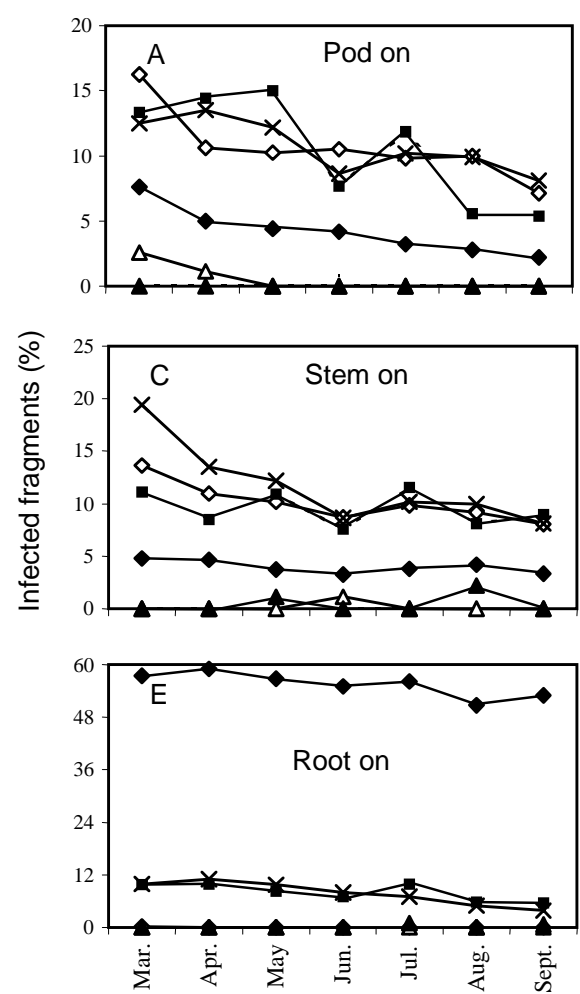

Month in all evaluations. From all the isolates of Fusarium spp.76\% were identified as F. solani, $10.9 \%$ as $F$. moniliform, $2.2 \%$ as $F$. equiseti, $2.2 \%$ as $F$. dimerum and $8.7 \%$ as $F$. oxysporum. Other fungi isolated were Myrothecium roridum, Penicillium sp., Chaetomiun sp., Epicoccum sp., Corynespora cassiicola and Trichoderma sp.

The percentage of survival of each pathogen based on the frequencies of isolation varied according to the month and the year (Figures 1 and 2). But, except for Fusarium spp., no consistent trends were observed. In 1998 the frequency of pathogens isolated from debris immediately after harvesting was higher than in 1999. Analysis of variance showed that the frequencies of survival of C. truncatum, $P$. sojae and $C$. kikuchii were significantly $(\mathrm{p} \leq 0.05)$ reduced between the first and the last evaluation either on
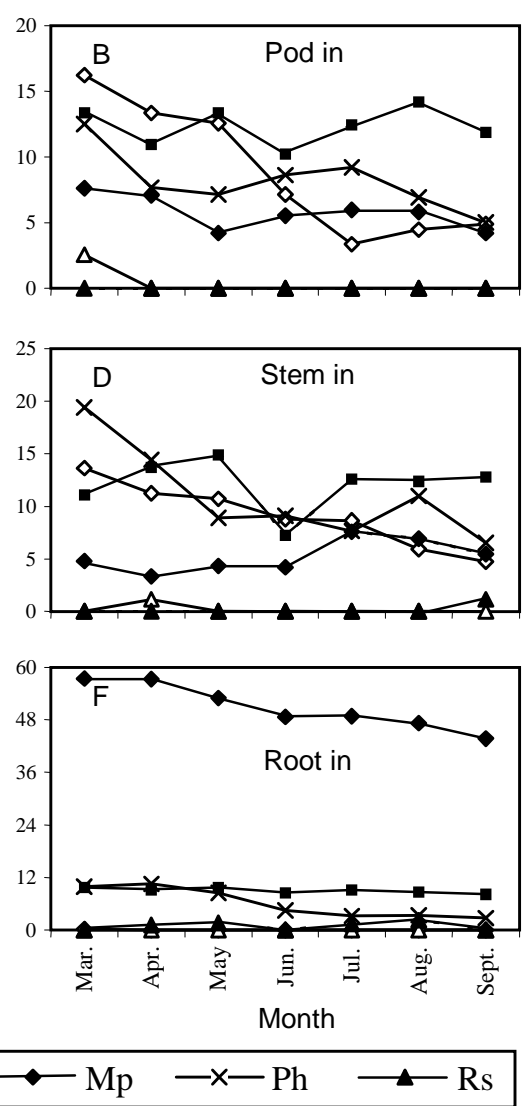

Figure 1. Percentage of incidence of Colletotrichum truncatum (Ct), Fusarium spp. (F), Cercospora kikuchii (Ck), Macrophomina phaseolina (Mp), Phomopsis sp. (Ph), Rhizoctonia solani (Rs), in soybean debris, on the soil and buried, during 1998. 
buried debris or in debris maintained on the soil surface for both years (Table 1). However, average survival was much more reduced in buried tissues than in tissue on the soil surface. Recovery of M. phaseolina was reduced with time in buried infected pods. However, buried stems and roots showed an increase in recovery of $R$. solani that was occasionally isolated in both years (Table 1). The recovery frequency of Fusarium spp. increased in buried debris. However, during dry periods the incidence of pathogens in all kinds of fragments was reduced either in debris on the soil surface or in buried debris (Table 1). Meteorological data for the period of April through September in 1998 and 1999 are shown in Figure 3. In 1998, the total amount of rain for the period of this study was higher than in 1999. Dry periods occurred in June 1998 and August 1999. Also,
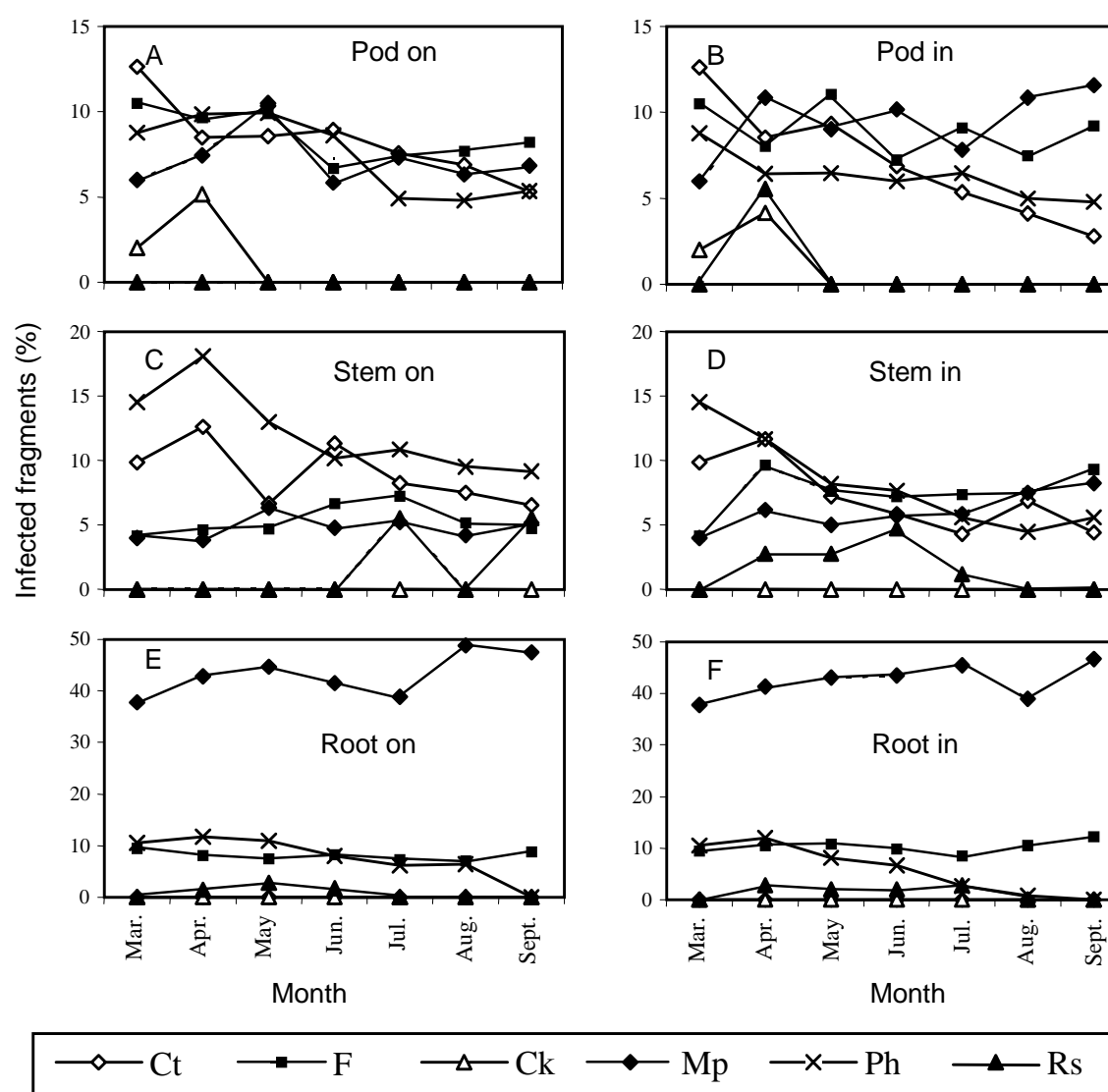

Figure 2. Percentage of incidence of Colletotrichum truncatum (Ct), Fusarium spp. (F), Cercospora kikuchii (Ck), Macrophomina phaseolina (Mp), Phomopsis sp. (Ph), Rhizoctonia solani (Rs), in soybean debris, on the soil and buried, during 1999. in 1998. smaller due to the lack of rain.
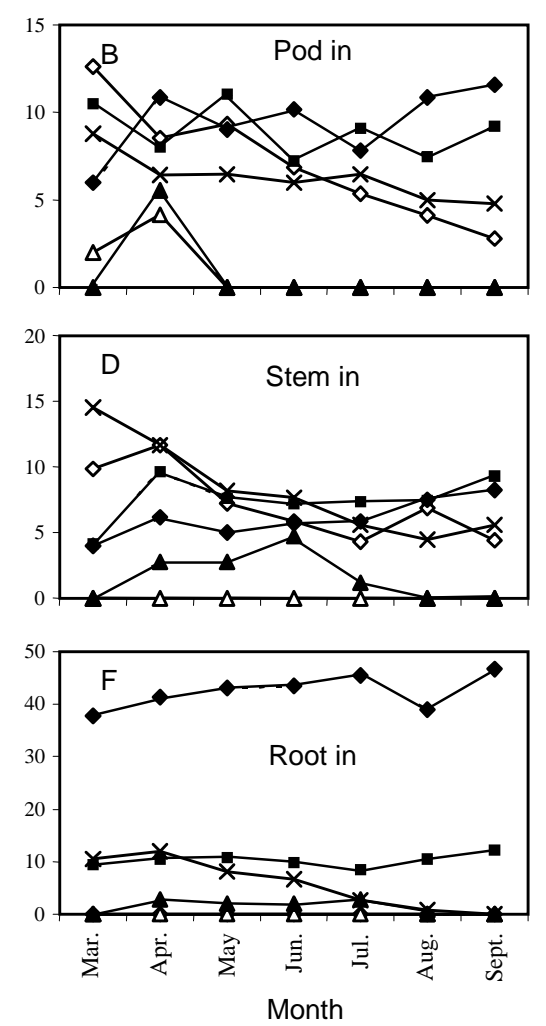

the average temperatures were lower in 1999 than

The loss of biomass, measured through the weight of debris along the period of this study showed that soybean debris were reduced $44.4 \%$ in the conventional system and $34.9 \%$ in the no-tillage system in 1998, when rain was better distributed during the period of observation (Figure 4). In 1999 the reduction was $48.2 \%$ and $39.0 \%$ for the conventional and no-tillage system, respectively. These data show that biomass loss in 1999 was faster at the beginning of the observation period due to accumulation of rain in the period (Figure 4). On the other hand, the biomass loss from the $8^{\text {th }}$ and the $16^{\text {th }}$ observation was

Results obtained in this work showed that the survival of the pathogens in both years was associated 
to the type of tissue used for evaluation as well as to the placement of the debris. Recovery of C. truncatum was higher from pods than from stems. In contrast, Phomopsis spp. was higher from stems than from pods. C. kikuchii was only isolated from pods. In terms of survival, all three fungi showed a decrease in survival during the period of evaluation. However, this decrease in survival was greater when the debris were buried. C. kikuchii was always isolated at the lowest percentage probably due to its low development in relation to other fungi which exhibit a faster mycelial growth. Moreover, it was not possible to recover it after the third month. Similar to the results of Baird et al. (1997), recovery of C. kikuchii was more frequent from pods than from stems.

On the other hand, Fusarium spp. and $M$. phaseolina showed an increase in survival when infected tissue was buried. Unlike airborne pathogens, soilborne pathogens took advantage of the organic matter incorporated into the soil for survival
(Pearson et al., 1984). This fact was mentioned by Boosalis \& Sharen (1959) who determined that $R$. solani survives primarily in colonized plant debris. The low frequency of Rhizoctonia sp. isolated from soybean debris in both years is in accordance with its low incidence in the field. However, Machado \& Gaudêncio (1993) detected at Campo Mourão County high incidence (38.8\%) of $R$. solani in soybean debris from a field previously cultivated with Lupinus albus, a crop used during the winter. Baird \& Carling (1998) also mentioned that this fungus was isolated exclusively from secondary roots in one year but was isolated from tap and secondary roots in another year. In this study, only middle tap roots were used, which may explain the low rate of $R$. solani isolation.

In relation to M. phaseolina, Wrather et al. (1998) observed that soil population densities were significantly greater in no-tillage than in either disk tillage or moldboard plowed plots. In this work, it was ob-

Table 1. Percent survival of pathogens isolated in soybean residues, on the soil surface or buried in the soil, immediately after harvesting and six months later ${ }^{(1)}$.

\begin{tabular}{|c|c|c|c|c|c|c|c|c|}
\hline \multirow[t]{2}{*}{ Residue } & \multirow{2}{*}{$\begin{array}{l}\text { Position in } \\
\text { relation to soil }\end{array}$} & \multirow[t]{2}{*}{ Date } & \multicolumn{6}{|c|}{ Pathogens $^{(2)}$} \\
\hline & & & $\mathrm{Ct}$ & F & $\mathrm{Ck}$ & $\mathrm{Mp}$ & $\mathrm{Ph}$ & Rs \\
\hline & & & \multicolumn{6}{|c|}{1998} \\
\hline \multirow[t]{3}{*}{ Pod } & On & $3 / 17$ & $16.22 \mathrm{a}$ & $13.33 \mathrm{a}$ & $2.55 \mathrm{a}$ & $4.22 b$ & $12.48 \mathrm{a}$ & 0.00 \\
\hline & On & $9 / 26$ & $7.11 b$ & $5.38 \mathrm{~b}$ & $0.00 \mathrm{~b}$ & $2.22 \mathrm{c}$ & $8.11 b$ & 0.00 \\
\hline & In & $9 / 26$ & $4.88 \mathrm{c}$ & $11.87 \mathrm{a}$ & $0.00 \mathrm{~b}$ & $7.55 \mathrm{a}$ & $5.00 \mathrm{~b}$ & 0.00 \\
\hline \multirow[t]{3}{*}{ Stem } & On & $3 / 17$ & $13.61 \mathrm{a}$ & $11.11 \mathrm{a}$ & 0.00 & $4.77 \mathrm{a}$ & $19.44 \mathrm{a}$ & 0.00 \\
\hline & On & $9 / 26$ & $8.05 b$ & $8.97 b$ & 0.00 & $3.33 b$ & $8.11 b$ & 0.00 \\
\hline & In & $9 / 26$ & $4.72 \mathrm{c}$ & $9.78 b$ & 0.00 & $7.44 \mathrm{a}$ & $6.50 \mathrm{c}$ & 1.11 \\
\hline \multirow[t]{4}{*}{ Root } & On & $3 / 17$ & $0.17 \mathrm{a}$ & $9.76 \mathrm{a}$ & 0.00 & $52.17 \mathrm{~b}$ & $6.70 \mathrm{a}$ & 0.00 \\
\hline & On & $9 / 26$ & $0.00 \mathrm{a}$ & $5.56 \mathrm{~b}$ & 0.00 & $51.33 b$ & $3.83 b$ & 0.67 \\
\hline & In & $9 / 26$ & $0.00 \mathrm{a}$ & $8.11 \mathrm{a}$ & 0.00 & $58.00 \mathrm{a}$ & $2.78 b$ & 0.00 \\
\hline & & & \multicolumn{6}{|c|}{1999} \\
\hline \multirow[t]{3}{*}{ Pod } & On & $3 / 27$ & $12.61 \mathrm{a}$ & $10.50 \mathrm{a}$ & $2.00 \mathrm{a}$ & $6.00 \mathrm{~b}$ & $8.78 \mathrm{a}$ & 0.00 \\
\hline & On & $9 / 27$ & $5.32 b$ & $8.22 \mathrm{a}$ & $0.00 \mathrm{~b}$ & $6.83 b$ & $5.33 b$ & 0.00 \\
\hline & In & $9 / 27$ & $2.78 \mathrm{c}$ & $9.22 \mathrm{a}$ & $0.00 \mathrm{~b}$ & $11.57 \mathrm{a}$ & $4.78 c$ & 0.00 \\
\hline \multirow[t]{3}{*}{ Stem } & On & $3 / 27$ & $9.83 a$ & $4.17 \mathrm{~b}$ & 0.00 & $4.00 \mathrm{~b}$ & $14.50 \mathrm{a}$ & 0.00 \\
\hline & On & $9 / 27$ & $6.53 b$ & $4.72 b$ & 0.00 & $5.17 b$ & $9.17 b$ & 0.00 \\
\hline & In & $9 / 27$ & $4.43 c$ & $9.34 \mathrm{a}$ & 0.00 & $8.22 \mathrm{a}$ & $5.61 \mathrm{c}$ & 0.00 \\
\hline \multirow[t]{3}{*}{ Root } & On & $3 / 27$ & 0.00 & $9.39 b$ & 0.00 & $37.78 b$ & $6.70 \mathrm{a}$ & 0.00 \\
\hline & On & $9 / 27$ & 0.00 & $8.81 b$ & 0.00 & $47.50 \mathrm{a}$ & $3.50 \mathrm{~b}$ & 0.00 \\
\hline & In & $9 / 27$ & 0.00 & $12.22 \mathrm{a}$ & 0.00 & $46.67 \mathrm{a}$ & $3.70 \mathrm{~b}$ & 0.00 \\
\hline
\end{tabular}

(1) Mean percentage based on the total number of fragments analyzed in each type of sample residue; means followed by the same letter are not different at $5 \%$ level of probability by Duncan test. ${ }^{(2)}$ Ct: Colletotrichum truncatum; F: Fusarium sp.; Ck: Cercospora kikuchii; Mp: Macrophomina phaseolina; $\mathrm{Ph}$ : Phomopsis sp.; Rs: Rhizoctonia solani. 
served that $M$. phaseolina recovery increased on buried fragments of stems and roots, suggesting that this fungus continues to grow on debris. This may be an important role in the epidemiology of this fungus and is in agreement with the report of Short et al. (1980) who observed that populations of viable sclerotia in pieces of soybean residues were as great or greater than the initial infestation levels showing an ability to survive and grow on crop residues. Similarly, Adee et al. (1997) observed that brown stem rot caused by Phialophora gregata was more severe in no-till cropping systems due to the longer survival of $P$. gregata on residue positioned on the soil surface (no till) than in buried residue (simulated conventional tillage).

In 1998, the survival of pathogens was higher than in 1999. This may have occurred because the initial amount of inoculum was higher in 1998 than in 1999, due to favorable environmental conditions. In addition, pathogen survival in 1999 may have been reduced due to a dry period between March and Sep- tember that did not occur in 1998. For instance, the frequency of Fusarium spp. isolation was always less during dry months.

These data show that under Brazilian conditions where continuous soybean cropping is largely used by farmers in a no-tillage system, there could be a significant enhancement in disease levels due to the increased survival of aerial soybean pathogens. According to Garzonio \& McGee (1983), the presence of soybean crop residue in the field induced more pod and stem blight infection, mainly on the continuous-soybean. Moreover, several researchers have demonstrated that soybean debris also harbors wheat and maize pathogens such as Fusarium graminearum, Gibberella zeae, Cochliobolus sativus and Leptosphaeria nodorum (Fernandez \& Fernandes, 1990; Baird et al., 1997).

On the other hand, soilborne pathogens were not affected as severely as the airborne pathogens. Sometimes the reduction in survival was not sufficient to have a great influence on disease occurrence. Spe-
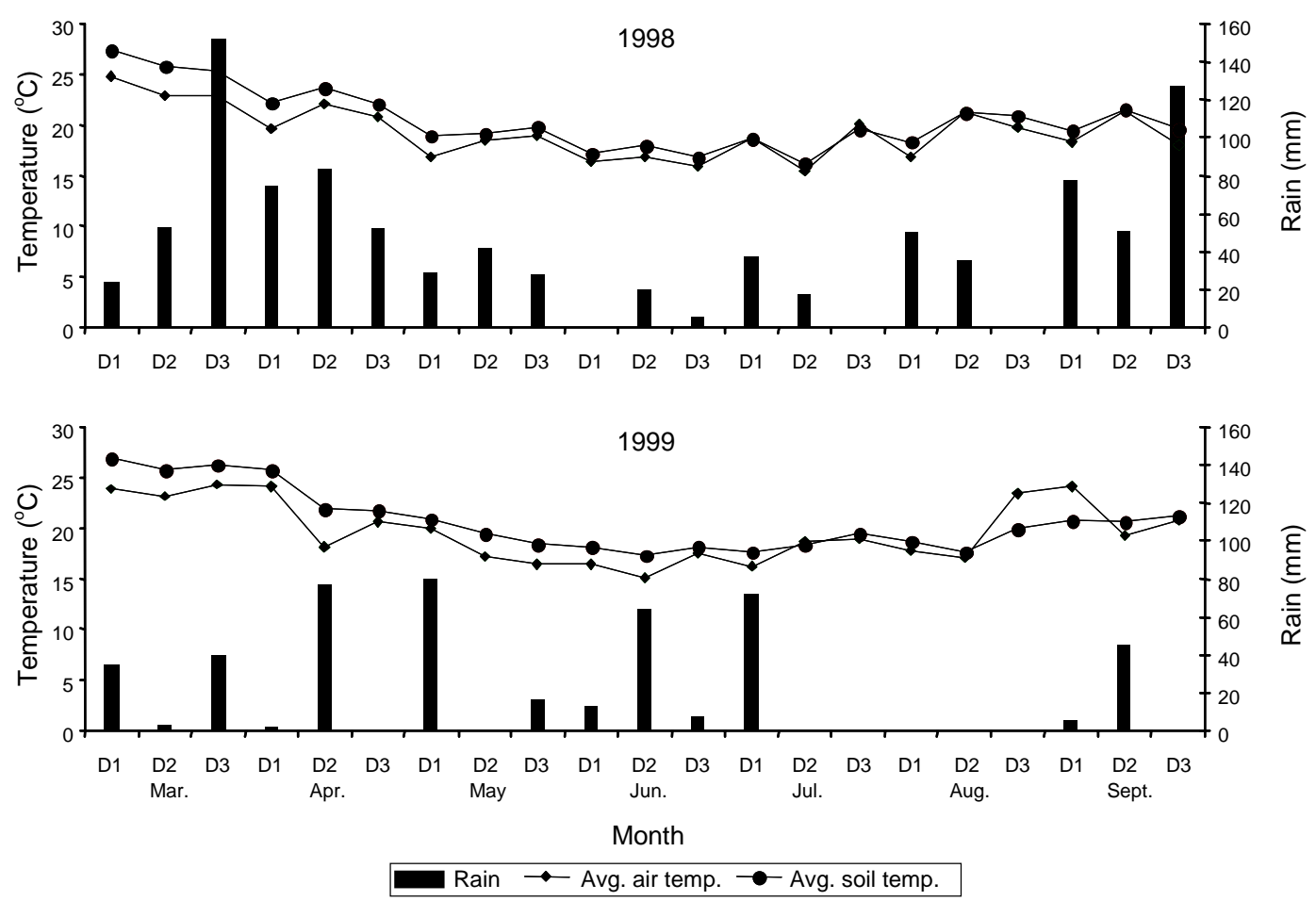

Figure 3. Averages of the first $\left(D_{1}\right)$, second $\left(D_{2}\right)$ and third $\left(D_{3}\right)$ ten-day monthly period of meteorological data from March through September of 1998 and 1999. 

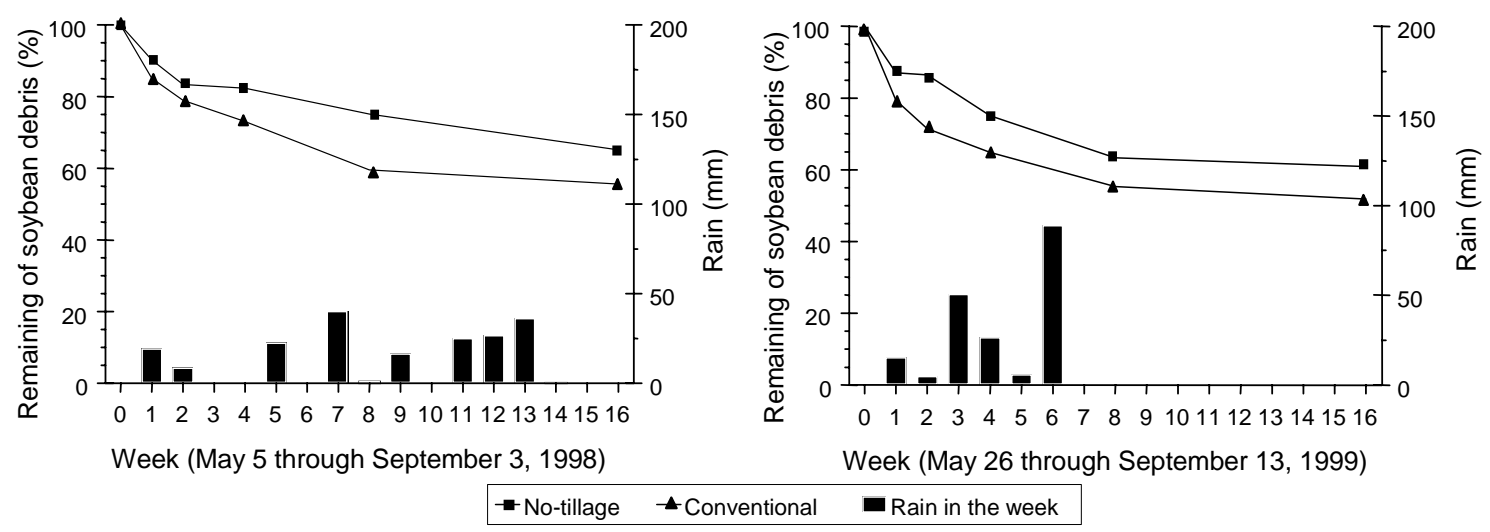

Figure 4. Weekly amounts of soybean debris in conventional and no-tillage systems and rainfall during the observation period.

cies of fungi known to cause diseases on soybean were still isolated six months after harvesting and two months before the soil preparation and sowing. This may provide inoculum that contributes to diseases development.

Residue decay and mineralization was faster in buried residues than in those on the surface due to better soil-residue contact. This was observed in the biomass reduction in the buried debris. However, the effect on pathogen survival depends on the specific microorganism. Airborne pathogens were severely affected by burying while soilborne pathogens were not.

From the results of this work it is possible to conclude that an adequate management system must be used by the farmers involving no-tillage system, crop rotation, resistant cultivars and seed treatment which controls seedborne pathogens, improves emergence and reduces post emergence diseases.

Although crop residues have been linked to diseases development, it is necessary to consider other parameters involved in the epidemiology. As mentioned by Fernandez et al. (1998) for residueborne pathogens, the amount of crop residues is not a good predictor of disease development. Factors such as the age of residues, amount and layering of residues, herbicide treatment and environmental conditions during and between growing seasons will determine the importance of residues as sources of inoculum for the next season.

The most important strategy to manage diseases under no-tillage is to plan in advance and use a reli- able crop for rotation which helps to restrict pathogen development, to breake the disease cycle and to lower the amount of the pathogen in the field. Results of Machado \& Gaudêncio (1993) and these results demonstrate that the amount of inoculum that overwinters on the soil surface is controlled through crop rotation.

\section{Conclusions}

1. Soybean pathogens that infect aerial plant parts survive less well when debris is buried as in the conventional system.

2. Soilborne pathogens such as Macrophomina phaseolina and Fusarium spp. survive and grow better in buried debris.

3. Soybean residues ensure survival of pathogens and provide most of the primary inoculum for some diseases.

4. Biomass decay is faster under conventional tillage system than under the no-tillage system.

\section{Acknowledgements}

To Dr. Maria Menezes for the identification of Fusarium species; to Luís C. Benato, Mauro Caetano and Ivan R. de Almeida for technical assistance; to Dr. José E. Pereira for help on statistical analysis; to Dr. C. Caio Machado, Dr. Norman Neumaier, Dr. Antônio R. Panizzi and Dr. John C. Rupe for their helpful reviews of an earlier draft of this paper; to $\mathrm{CNPq}$ for providing a fellowship to A.M.R.A. 


\section{References}

ADEE, E. A.; GRAU, C. R.; OPLINGER, E. S. Population dynamics of Phyalophora gregata in soybean residue. Plant Disease, St. Paul, v. 81, n. 1, p. 199-203, 1997.

ALMEIDA, A. M. R. Estudo preliminar da sobrevivência de patógenos de soja em restos de cultura coletados nos sistemas de plantio direto e convencional. In: EMBRAPA. Centro Nacional de Pesquisa de Soja (Londrina, PR). Resultados de pesquisa de soja 1979/80. Londrina, 1980. p. 113-115.

BAIRD, R.; CARLING, D. Survival of parasitic and saprophytic fungi on intact senescent cotton roots. Journal of Cotton Science, Memphis, v. 2, p. 27-34, 1998.

BAIRD, R. E.; MULLINIX, B. G.; PEERY, A. B.; LANG, M. L. Diversity and longevity of the soybean debris mycobiota in a no-tillage system. Plant Disease, St. Paul, v. 81, n. 5 , p. 530-534, 1997.

BOOSALIS, M. G.; SHAREN, A. L. Methods for microscopic detection of Aphanomyces euteiches and Rhizoctonia solani and for isolation of Rhizoctonia associated with plant debris. Phytopathology, St. Paul, v. 49,n. 1, p. 192-198, 1959.

COOK, R. J.; BOOSALIS, M. G.; DOUPNIK, B. Influence of crop residues on plant disease. In: OSCHWALD, W. R. (Ed.). Crop residue management systems. Madison: American Society of Agronomy/Crop Science Society of America/Soil Science Society of America, 1978. p. 147-163. (Special Publication, 31).

COSTAMILAN, L. M.; LHAMBY, J. C. B.; BONATO, E. R. Sobrevivência de fungos necrotróficos em restos de cultura de soja, em sistema de plantio direto. Fitopatologia Brasileira, Brasília, v. 24, n. 1, p. 175-177, 1999.

FERNANDEZ, M. R.; FERNANDES, J. M. C. Survival of wheat pathogens in wheat and soybean residues under conservation tillage systems in southern and central Brazil. Canadian Journal of Plant Pathology, Guelph, v. 12, p. 289-294, 1990.

FERNANDEZ, M. R.; McCONKEY, B. G.; ZENTNER, R. P. Tillage and summerfallow effects on leaf spot diseases of wheat in the semiarid Canadian Prairies. Canadian Journal of Plant Pathology, Guelph, v. 20, p. 376379, 1998.

GARZONIO, D. M.; McGEE, D. C. Comparison of seeds and crop residues as sources of inoculum for pod and stem blight of soybeans. Plant Disease, St. Paul, v. 67, n. 12, p. $1374-1376,1983$.

KMETZ, K. T.; ELLET, C. E.; SCHMITTHENER, A. F. Soybean seed decay: sources of inoculum and nature of inection. Phytopathology, St. Paul, v. 69, n. 7, p. 798-801, 1979.

MACHADO, C. C.; GAUDÊNCIO, C. A. Avaliação da incidência de patógenos em planta e atividade microbiana no solo em sistema de rotação soja/milho sucedida por trigo, adubação verde e cobertura morta do solo com alternância de preparo do solo e semeadura direta. In: EMBRAPA. Centro Nacional de Pesquisa de Soja (Londrina, PR). Resultados de pesquisa de soja 1989/90. Londrina, 1993. p. 198-205. (Documentos, 125).

PEARSON, C. A. S.; SCHWENK, F. W.; CROWE, F. J.; KELLEY, K. Colonization of soybean roots by Macrophomina phaseolina. Plant Disease, St. Paul, v. 10, n. 68, p. 1086-1088, 1984.

RONCADORI, R. W.; McCARTER, S. M.; CRAWFORD, J. L. Evaluation of various control measures for cotton boll rot. Phytopathology, St. Paul, v. 65, n. 5, p. 567-570, 1975.

ROTHROCK, C. S.; HOBBS, T. W.; PHILLIPS, D. V. Effects of tillage and crop systems on incidence and severity of southern stem canker of soybean. Phytopathology, St. Paul, v. 75, n. 11, p. 1156-1159, 1985.

RUPE, J. C.; ROBBINS, R. T.; GBUR, E. E. Effect of crop rotation on soil population densities of Fusarium solani and Heterodera glycines on the development of sudden death syndrome of soybean. Crop Protection, Oxford, v. 16 , n. 6. p. 575-580, 1997.

SARAIVA, O. F.; TORRES, E. Manejo dos resíduos da colheita, condicionado por sistemas de preparo do solo. In: EMBRAPA-Centro Nacional de Pesquisa de Soja (Londrina, PR). Resultados de pesquisa da Embrapa Soja: 1999. Londrina, 2000. p. 103-104.

SATURNINO, H. M. O plantio direto como promotor da qualidade ambiental e prosperidade na agricultura. In: CONGRESSO BRASILEIRO DE ECONOMIA E SOCIOLOGIA RURAL, 36., 1998, Poços de Caldas. Agronegócio brasileiro: desafios e perspectivas. Brasília: Sociedade Brasileira de Economia e Sociologia Rural, 1998. p. 105-115.

SHORT, G. E.; WYLLIE, T. D.; BRISTOW, P. R. Survival of Macrophomina phaseolina in soil and residue of soybean. Phytopathology, St. Paul, v. 70, n. 1, p. 13-17, 1980.

STRAHLER, A. N. Classification of global climates. In: PHYSICAL geography. 4. ed. New York: J. Wiley, 1975. part III, p. 243-245.

WRATHER, J. A.; KENDIG, S. R.; TYLER, D. D. Tillage effects on Macrophomina phaseolina population density and soybean yield. Plant Disease, St. Paul, v. 82, n. 2, p. $247-250,1998$. 